Список литературы

1. Государственный архив Иркутской области. Ф. 50. ОП. 1. Д. 9100. Отчет о состоянии Залогского миссионерского стана за 1911 г.

2. Любимов П. П. Религии и вероисповедный населения Азиатская Россия// Азиатская Россия. Т.1. Люди и порядки за Уралом. СанктПетербург, 1914. С. 200-242.

3. Дулов А. В., Санников А. П. Православная церковь в Восточной Сибири в XVII - начале XX веков. Ч. 2. Иркутск, 2006. 323 с.

4. Елисеев Е. свящ., миссионер. Практические советы и разъяснения по вопросам миссионерской практики // Тобольские епархиальные ведомости. 1908. № 23. С. 458-461.

5.Иркутские епархиальные ведомости. 1868. № 25.

6. Иркутские епархиальные ведомости. 1870. № 40 .

7. Иркутские епархиальные ведомости. 1895. № 9 .

8. Иркутские епархиальные ведомости. 1915. № 9.

9. Кулаков П. Е. Буряты Иркутской губернии // Известия ВСОИРГО. Иркутск, 1895. Т. 26. Вып. 4/5. С. 118-166.

10. Тихонов B. B. Историко-культурное наследие Предбайкалья и перспектива его сохранения методом этнографических музейных комплексов под открытым небом. Иркутск, 2013. 364 c.

11. Тихонов В. В. Перспективы музеефикации элементов православной миссионерской деятельности второй половины XIX - начала XX века в Иркутской области // Наследие святителя Иннокентия (Вениаминова) и православная миссионерская деятельность в Сибири, на Дальнем Востоке и сопредельных территориях. Иркутск, 2015. С. 193-198.

12. Тихонов В. В. Перспективы скансенологической практики Иркутской области по актуализации материального наследия православной миссионерской деятельности середины XIX начала XX в. // Православие и дипломатия в странах Азиатско-Тихоокеанского региона. Улан-Удэ, 2020. 192 с.

13. Труды православных миссий Иркутской enархии: т. 1-4. Иркутск: Издание Иркутского комитета православного миссионерского общества, 1884. Тип. Н. Н. Синицина. Т. 2: 1868 1872 гг., 1886, [4]. 632 с.

14. Труды православных миссий Иркутской enapхuи: т. 1-4 гг. Иркутск: Издание Иркутского комитета православного миссионерского общества; Тип. Н. Н. Синицина. Т. 4: 18781883 гг., 1886.678 с.

15. Шерстобоев В. Н. Илимская пашня. T. 1: Пашня Илимского воеводства XVII и начала XVIII в. Иркутск, 1949. 596 с.

16. Якобий А. И. О миссионерском стане в стране Надыма и о возможной поставке христианской миссии в странах русского инородческого Севера. Тобольск: Типография Тобольского Епархиального братства, 1895, [2]. 48 с.

Алтайский государственный педагогический университет (Барнаул, Россия) muzey.obrazovania@yandex.ru

Научный руководитель - О. Н. Труевцева, доктор исторических наук, профессор Алтайский государственный педагогический университет (Барнаул, Россия) truevtseva@yandex.ru

\title{
ДЕЯТЕЛЬНОСТЬ МУЗЕЯ ИСТОРИИ ОБРАЗОВАНИЯ ИМ. П. П. КОСТЕНКОВА С 1991 ПО 2021 ГОДЫ
}

Аннотация. В статье представлена краткая история становления Музея истории образования им. П. П. Костенкова. Анализируется состав фондового собрания музея и экспозиционно-выставочная работа. Раскрываются возможности музея в сохранении и популяризации наследия педагогического сообщества Алтайского края и Алтайского государственного педагогического университета.

Ключевые слова: музей, фонды, экспозиция, выставка, история образования, педагогический вуз, наследие. 
Более 45 лет назад началась история музея, посвященного теме народного образования в Алтайском крае. Обстоятельства, способствовавшие этому, описаны в брошюре «Путеводитель по музею» его идейным вдохновителем профессором, доктором педагогических наук Павлом Павловичем Костенковым. Официальное открытие Музея просвещения и культуры Алтая состоялось 19 января 1978 г. в Алтайском государственном университете (г. Барнаул). Однако в молодом вузе не смогли найти подходящего помещения для размещения музейных экспонатов и картинной галереи. Поэтому в 1985 году было принято решение передать часть музейного собрания в среднюю школу № 110 г. Барнаула [1, с. 3-4]. Музей расположился в помещении школьной комнаты боевой славы. В экспозицию вошли школьные учебники конца XIX - начала XX века; образцы документов об образовании начала XX века; рукопись книги «Два детства» С. П. Титова; фотографии педагогов и школ; труды Горно-Алтайского научноисследовательского института истории, языка и литературы; модели машин, изготовленных ребятами на станции юных техников и в краевом Дворце пионеров [2]. Члены педагогического и школьного коллектива школы, в первую очередь методист школы В. И. Колтунова, директор школы А. И. Ипполитов принимали живое участие в судьбе музея, его сохранении и развитии.

И все же экспозиция не могла в полной мере выполнять свою задачу - быть краевым музеем истории образования.

Понимая особую значимость музея для воспитания будущих педагогов, изучения, сохранения и популяризации педагогического наследия региона, П. П. Костенков обратился к председателю краевого отделения Педагогического общества Российской Федерации, профессору, ректору В. Н. Гончарову с предложением об открытии музея на базе Барнаульского государственного педагогического института [3, с. 75]. П. П. Костенков считал, что музей необходим педагогическому вузу как идеологический, научный, методический центр, как условие повышения эффективности профессионально-педагогической подготовки кадров для края. Руководством Барнаульского государственного педагогического института (далее - БГПИ, АлтГПУ, АлтГПА) было принято положительное решение об открытии Музея истории образования при кафедре управления развитием образования факультета повышения квалификации организаторов народного образования с 1 августа 1991 г. [4, с. 135]. Для музея выделили помещение, которое ранее занимал Народный музей В.И. Ленина в учебном корпусе на пр. Социалистическом, 126. Профессор П. П. Костенков был утвержден председателем Совета музея. Первым заведующим музея стала Светлана Васильевна Бажина, выпускница факультета иностранных языков БГПИ [4, с. 136]. Из фондов музея школы № 110 было передано около 1800 экспонатов и 2000 экспонатов собрано энтузиастами Народного музея В. И. Ленина. Началась кропотливая работа по подготовке экспозиции первого зала, посвященного народному образованию на Алтае в дореволюционный период (с 1753 по 1917 гг.). Торжественное открытие экспозиции состоялось 25 января 1992 года. Именно дата открытия первой экспозиции считалась началом деятельности музея в вузе. В ноябре 1992 г. был открыт второй зал Музея, посвященный истории народного образования с 1917 до начала 1990-х годов. Для этого специально провели реконструкцию центрального фойе 3 этажа. Общая площадь двух выставочных помещений составила более $116 \mathrm{~m}^{2}$. Галерея почти из ста фотопортретов заслуженных учителей Алтайского края расположилась в прилегающем фойе. Это было особенно значимо для педвуза, поскольку многие известные заслуженные учителя были выпускниками БГПИ и пятеро из них работали в педагогическом институте.

На базе музея проводилась работа с организаторами школьных музеев и экскурсоводов из числа студентов 1-2 курса отделения музееведения факультета дополнительного педагогического образования, руководитель - С. В. Бажина. Общее число студентов, прошедших обучение за это время, составляет 203 человека. Процесс обучения студентов-музееведов был организован через работу педагогического клуба «Друзья музея». На собраниях клуба составлялся план работы музея, проходила защита рефератов, отмечались памятные даты в истории развития образования Алтайского края. Студенты вовлекались во все процессы музейной работы: выявление музейных предметов, учет и хранение, подготовка тематических выставок, написание текстов экскурсий. Студенческие рефераты и материалы по истории школ различных районов Алтайского края пополнили фонды музея [5].

Имея в своем распоряжении фонд диссертационных работ и авторефератов, выпускных работ слушателей факультета повышения квалификации, базу данных «Образование», организовывая выставки трудов ученых педагогиче- 
ского вуза, предоставляя литературу слушателям, музей в указанный период времени в определенной степени аккумулировал функции методического кабинета.

Профессор П. П. Костенков принимал самое активное участие в планировании направлений научно-исследовательской и поисковой работы музея. При его участии было подготовлено и проведено три научно-практических конференции, две из которых - краевые, были посвящены 110-летию Общества попечения о начальном образовании (1995 г.) и 110-летию писателя и просветителя А. М. Топорова (2001 г.). Опубликованы «Книга памяти учителей и других работников образования, погибших в годы ВОВ» в 2 частях (1995), «Путеводитель по музею» (1997), множество статей в вузовской газете «Учитель». Под руководством П. П. Костенкова авторским межвузовским коллективом была подготовлена к изданию 3-х томная «Энциклопедия образования в Западной Сибири» (2003).

В 2008 г. П. П. Костенковым была подготовлена к публикации монография, посвященная заслуженному учителю школы РСФСР, педагогу-литератору С. П. Титову, отцу летчикакосмонавта СССР Г. С. Титова.

Благодаря переписке профессора П. П. Костенкова и профессора А. П. Уманского в начале 1990-х гг. фонды музея пополнились уникальной коллекцией, состоящей из личных вещей, фотографий и документов А. П. Щекотинского, первого директора Барнаульского учительского института. К 120-летию со дня рождения А. П. Щекотинского была подготовлена статья с описанием коллекции для издания Алтайской краевой универсальной научной библиотеки им. В.Я. Шишкова «Алтайский край, 2021 г.: календарь знаменательных и памятных дат». Для вуза особую ценность имеют личные воспоминания А. П. Щекотинского о первых годах становления первого вуза Алтая [6, c. 112-116].

Еще в 1982 г. под редакцией П. П. Костенкова вышла брошюра «Жизнь посвящаю детям» о руководителе первого детского дома на Алтае В. С. Ершове. Все материалы, которые были собраны во время подготовки издания, автор передал в фонды музея. Это копии документов из музея В.С. Ершова в селе Алтайском: авторские копии писем Ершова к М. И. Калинину, фотографии и биографии воспитанников. В 2020 г. к 150-летию со дня рождения В. С. Ершова на основе данных материалов была подготовлена виртуальная фотовы- ставка, которую дополнили подлинные документы. Использование виртуальных фотовыставок в музее, их дальнейшая публикация на интернет-странице музея, позволили сделать процесс презентации документов для посетителей музея более доступным, мобильным, привлекли к данному проекту большее количество посетителей.

К 80-летию первого вуза Алтая проект П. П. Костенковым совместно с профессором В. Н. Филипповым был инициирован и в дальнейшем реализован проект по созданию информационно-справочного общевузовского ресурса - «Электронной энциклопедии АлтГПУ» (2011). Главная цель проекта по выявлению поименного списка выпускников 1935-2010 гг. и созданию биографических статей о 1409 преподавателях была достигнута [7]. Таким образом, почетный профессор АлтГПА, доктор педагогических наук, профессор, член Союза писателей России П. П. Костенков внес весомый вклад в сохранение и преумножение памяти о педагогическом наследии Алтайского края и Сибири.

В 2006 г. сотрудниками музея был инициирован проект по реконструкции двух музейных залов; кроме того, назрела необходимость в выделении отдельного помещения под хранение фондов музея. Для выполнения дизайна проекта реконструкции привлекли студентов Института архитектуры и дизайна Алтайского государственного технического университета им. И. И. Ползунова (г. Барнаул). 15 мая 2009 г. музей открылся после реконструкции, в результате которой два зала были объединены в одно просторное помещение. После реконструкции музей в свое распоряжение получил обновленный зал и оборудование, соответствующее современным требованиям к экспозиционным музейным пространствам. Условно экспозиционное пространство разделилось на две части: «История и развитие АлтГПУ» и «История народного образования в Алтайском крае». В экспозицию была включена выставка, посвященная Т. Г. Митьковской - Герою Социалистического труда и выпускнице физикоматематического факультета БГПИ 1951 года; выставка книг из собрания учебной литературы с конца XIX до XXI вв.; атрибуты пионерской организации; коллекция писчих принадлежностей конца XIX в. - середины XX в.

К этому времени значительно оживилась рекламная деятельность музея. На сайте АлтГПУ появилась страница музея, с информацией о выставках, фоторепортажами с музейных 
мероприятий и статьями, которые готовили сотрудники музея и вуза [8].

С 1 сентября 2010 г. до 1 марта 2017 г. на базе Музея истории образования функционировал Музейный центр АлтГПУ. Директором была назначена Т. В. Мазурова, выпускница исторического факультета АлтГПУ. Научным консультантом приглашена д. ист. н., профессор О. Н. Труевцева [9]. Необходимо уточнить, что О. Н. Труевцева была принята в Совет Музея еще в 2007 году.

В 2014 г. Музейный центр возглавила Ю. Б. Щербакова.

2017 год был особым: исполнилось 25 лет со дня открытия первой выставки в Музее истории образования и 90 лет его основателю, профессору П. П. Костенкову. В знак признания вклада в сохранение историко-культурного наследия системы образования Алтайского края Ученым советом АлтГПУ было принято решение о присвоении Музею имени П. П. Костенкова [10]. В Музее к этому событию была подготовлена юбилейная выставка «Просвещения свет», на которой гости могли познакомиться с фотографиями из семейного архива П. П. Костенкова, его наградами, публикациями и монографиями [11].

Тема участия преподавателей университета в Великой Отечественной войне была одной из важных и значимых на протяжении многолетней истории деятельности Музея. При подготовке к 70-летию Победы в Великой Отечественной войне, например, сотрудники Музея приняли участие в проекте научнопедагогической библиотеки АлтГПУ по созданию электронного биобиблиографического указателя «Поклонимся великим тем годам...». На тот момент в архиве вуза было выявлено 140 фамилий преподавателей, сотрудников и студентов БГПИ и БУИ, которые воевали на фронте. За последние 6 лет выявлено еще 14 фамилий. Проект продолжает пополняться биографическими материалами и рассказывать современной молодежи о жизни и подвигах наших земляков.

Наличие в собрании музея личных коллекций выпускников и преподавателей-ветеранов позволило принять участие в проекте Военноисторического отдела Алтайского государственного краеведческого музея «Солдатское письмо Великой Отечественной войны 19411945 гг.» и спецпроекте радиостанции «Вести FM» «Письма с фронта» (2015). Участие в проектах позволяет не только представить широкой публике имеющиеся музейные предметы, но и приобрести новые контакты, установить связь с потенциальными дарителями. Так участие во всероссийской акции «Мы не были на той войне», стало причиной знакомства с А. Н. Коган. Благодаря этому коллекция М. Л. Когана (выпускника БГПИ 1957 г.) пополнилась уникальными документами [12].

Плодотворным для музея стало сотрудничество с Р.Г. Носоновым, научным сотрудником Лаборатории исторического краеведения исторического факультета АлтГПУ, ветераном педагогического труда, удостоенного почетного звания Учитель учителей. Фотографии и документы из музейных фондов были использованы для работы над сборниками: «История института физической культуры и спорта Алтайского государственного педагогического университета в событиях и лицах» (2015); учебнометодическим пособием «Алтайская государственная педагогическая академия - первый вуз Алтая в документах и материалах» в 3 частях (2013, 2014, 2020); «Исторический факультет Алтайского государственного педагогического университета. Летопись (1933-2018 годы)» (2018); «Хронология кафедры историкокультурного наследия и туризма АлтГПУ» (2018); «Их имена хранить в бессмертных списках... Первый вуз Алтая - Великой Победе!» (2020). Последнее издание удостоено Диплома в номинации «Лучшее издание библиотек» по итогам VIII Дальневосточного регионального конкурса изданий высших учебных заведений «Университетская книга - 2021», который проходил на базе Дальневосточного федерального университета (г. Владивосток) [13].

Личные коллекции из фондов музея становятся основой для подготовки юбилейных и тематических выставок, посвященных нашим преподавателям и выпускникам. В 2018 г. к 90летию Т. Г. Митьковской существующая экспозиция была дополнена новыми поступлениями. Их передал в музей А. И. Митьковский, сын выдающегося учителя Алтайского края [14].

К 90-летию со дня рождения ветерана тыла и педагогического труда В.Ф. Сизых, выпускницы филологического факультета БГПИ 1946 г., было подготовлено мероприятие с участием студентов филологического факультета. Ребята зачитывали фрагменты её воспоминаний о начале Великой Отечественной войны, учебе и жизни в тылу [15]. Личные коллекции преподавателей и студентов исторического и филологического факультетов чаще, чем другие пополняются образцами литературного творчества. В фонды музея передают свои мемуары, стихи, 
прозу, авторские методические материалы по преподаваемым дисциплинам (например, Л.Н.Ульянов， М. Л. Коган， М.Н.Целебровский и др.). Конечно, чаще всего авторы передают печатные издания и статьи. Что тоже является ценным музейным предметом, поскольку в нем зафиксирован результат научной, методической и воспитательной деятельности педагогов. В целом за время существования Музея его фонды увеличились в 3 раза - до 6500 единиц хранения.

В собрании Музея бережно хранятся материалы по истории учреждений системы образования г. Барнаула и Алтайского края. Например, печатные издания Алтайского краевого института повышения квалификации работников образования (ныне Алтайский институт развития образования им. А. М. Топорова): брошюры, методическая литература, проспекты о передовом педагогическом опыте, плакаты, учебные планы и т. д. Эти материалы и фотографии были использованы при подготовке книги к 80-летию института «Почти ровесник краю» (2019) [16]. Как отметила Е. М. Клишина, одна из её авторов: «Брошюры и плакаты, что сохранились в Музее теперь настоящая редкость, их нет даже в библиотеке АКИПКРО».

В октябре 2020 г. ко Дню Учителя Музей стал центральной площадкой фотовыставки «Учителя в Великой Отечественной войне» в Алтайском крае. Эта экспозиция была частью проекта «Большая история». В муниципалитетах также был поддержан этот патриотический проект выставками о земляках-учителях, воевавших на фронте. Идея проекта, который охватил всю страну, принадлежала Молодежному Парламенту при Государственной Думе РФ. В Алтайском крае организаторами проекта стали Молодежный парламент Алтайского края и АлтГПУ. Для оформления фотовыставки был разработан единый дизайн. Благодаря этому в новостных лентах репортажи о мероприятии были легко узнаваемы [17].

Музей активно участвует в жизни вуза и города: готовит выставки к юбилейным датам преподавателей и выдающихся выпускников, участвует в научно-практических конференциях, в образовательных и патриотических проектах, проводит мастер-классы для студентов и школьников, принимает в своих стенах выставки из других музеев, в краевых мероприятиях таких как «Музейная ночь» [18].

Таким образом, за годы существования в АлтГПУ Музее истории образования им. П. П. Костенкова его сотрудниками была выполнена большая работа по сбору уникаль- ных и интереснейших коллекций, их хранению и популяризации. Впереди - юбилей университета и Музей сделает все возможное для сохранения и преумножения фондов, создания новой экспозиции, соответствующей современным возможностям и требованиям.

\section{Список литературы}

1. Путеводитель по музею истории и развития образования в Алтайском крае. Барнаул, $1997.33 \mathrm{c}$.

2. Костенков П. П. Музей в университете // Алт. правда. 1979. 3 марта. 4 с.

3. Костенков П. П. Годы прожитые. Личные воспоминания о прошлом. Барнаул, 2012. $168 \mathrm{c}$.

4. Алтайская государственная педагогическая академия - первый вуз Алтая в документах и материалах. Часть III: 1973-1993 годы. Барнаул, $2020.186 \mathrm{c}$.

5. Музей истории образования им. П. П. Костенкова : Отчеты о работе музея за 20032009 гг.

6. Алтайский край, 2021 д.: календарь знаменательных дат и памятных дат. Барнаул, 2020. $242 \mathrm{c}$.

7. Электронная энииклопедия АлтГПУ // Алтайский государственный педагогический университет. URL: http://enc.altspu.ru/ (12.03.2021).

8. Музей истории образования имени П. П. Костенкова. URL: https://old.altspu.ru/mc/. (12.03.2021).

9. Музей истории образования им. П. П. Костенкова : Приказ о создании Музейного центра от 31 августа 2010 г. № 119/1п.

10. Музей истории образования им. П. П. Костенкова : Приказ о создании музея истории образования имени П. П. Костенкова от 20 февраля 2017 г. № 37/1п.

11. Просвещения свет // Алтайский государственный педагогический университет. URL: https://old.altspu.ru/mc/mc_action/22369-prosvescheniya-svet.html (13.03.2021).

12. Щербакова Ю. Б., Широков О. В. Роль Музейного центра в сохранении и изучении историко-культурного наследия АлтГПУ // Алтайский государственный педагогический университет. URL: // https://old.altspu.ru/mc/mc library/page/2/ (12.02.2021).

13. Книги преподавателей и сотрудников вуза - победители конкурса «Университетская книга - 2021»// Алтайский государственный педагогический университет. URL: // 
https://www.altspu.ru/about_the_university/news/1 3193/ (20.04.2021).

14. Щербакова Ю. Б. Личная коллекция учителя Т. Г. Митьковской в собрании музея истории образования им. П. П. Костенкова //Сохранение и изучение культурного наследия Алтайского края. Барнаул, 2021. Вып. XXVII. C. 429-433.

15. Судьба и Родина едины // Алтайский государственный педагогический университет. URL: // https://www.old.altspu.ru/mc/mc_action/page/2/ (20.03.2021).

16. К 80-летию АКИПКРО // Алтайский государственный педагогический университет.
URL: // https://www.old.altspu.ru/mc/mc_library/28250-k-80-letiyu-akipkro.html/ (21.03.2021).

17. Фотовыставка «Учителя в Великой Отечественной войне» в АлтГПУ // Алтайский государственный педагогический университет. URL: // https://www.old.altspu.ru/mc/mc_action/ 31127-fotovystavka-uchitelya-v-velikoy-otechestvennoy-voyne-v-altgpu.html (20.02.2021).

18. Как мы провели «Ночь музеев» // Алтайский государственный педагогический университет. URL: // https://www.old.altspu.ru/mc /mc_action/32262-kak-my-proveli-noch-muzeev2021.html (20.03.2021).

УДК 379.852(571.15): 659.125.37+291.13(571.15)

DOI: $10.32340 / 2514-772 X-2021-1-67-71$

В. С. Яговец, доцент

Алтайский государственный институт культуры (Барнаул, Россия) viton@inbox.ru

Н. Н. Беспалова, кандидат педагогических наук, доцент Алтайский государственный институт культуры (Барнаул, Россия) natalya.bespalova.92@mail.ru

\section{ИСПОЛЬЗОВАНИЕ ИСТОРИКО-КУЛЬТУРНОГО ПОТЕНЦИАЛА ТЕРРИТОРИИ В ТУРИСТИЧЕСКОМ МИФОТВОРЧЕСТВЕ (НА ПРИМЕРЕ АЛТАЙСКОГО КРАЯ)}

Аннотация: В статье рассматриваются вопросы, связанные с использованием историкокультурного потенциала территории в таком туристическом явлении как мифотворчество. Мифология пространства является важнейшей частью культуры местного населения и влияет на формирование образа территории. Это, в свою очередь, отражается на восприятии данной территории посещающими ее туристами. Мифы, отображающие культурную специфику места, выражают его дух, который наряду с городскими легендами влияет на формирование географического образа, особую атмосферу места, его культурную идентичность, что в свою очередь, выступает решающим фактором при выборе места для совершения путешествия туристами. Авторы анализируют основные элементы мифологизации туристского пространства, различные виды классификаций мифов и принципы их создания. В статье также приводятся актуальные примеры создания мифов в сфере туризма на территории Алтайского края.

Ключевые слова: мифология пространства, мифотворчество в туризме, туристское легендирование, легендирование образа Барнаула, мифологизаџия пространства туристских территорий Алтайского края.

Современными исследователями замечено, что разум человека мифологичен и бессознательно соотносит объективную информацию об окружающем мире с субъективным опытом, собственными впечатлениями и фантазией. Мифологичность разума в процессе развития цивилизации использовалась стихийно или осознанно как в глобальном, так и в локальном масштабах.
Мифологизацию пространства исследователи определяют как «процесс генерации художественных образов на основе реальных свойств и событий, с этой территорией связанных» [1]. Основой для формирования мифологического пространства являются легенды, эпос, народные предания, художественный вымысел, устное народное творчество, рассказы очевидцев о мистических событиях и т. п. 